\title{
Article
}

\section{Why Is the Invasive Plant Sphagneticola trilobata More Resistant to High Temperature Than Its Native Congener?}

\author{
Minling Cai ${ }^{\dagger}$, Xiaohua Lin $^{\dagger}$, Jindi Peng ${ }^{\dagger}$, Junjie Zhang, Minghao Chen, Jundong Huang, Lihua Chen, Feng Sun, \\ Wenqiao Ding and Changlian Peng*
}

Guangzhou Key Laboratory of Subtropical Biodiversity and Biomonitoring, Guangdong Provincial Key Laboratory of Biotechnology for Plant Development, College of Life Sciences, South China Normal University, Guangzhou 510631, China; 2020010178@m.scnu.edu.cn (M.C.); 20172521046@m.scnu.edu.cn (X.L.); 20172521085@m.scnu.edu.cn (J.P.); 2019022505@m.scnu.edu.cn (J.Z.); 2017022212@m.scnu.edu.cn (M.C.); 2019022493@m.scnu.edu.cn (J.H.); 2020022828@m.scnu.edu.cn (L.C.); 20198889@m.scnu.edu.cn (F.S.); 2018022497@m.scnu.edu.cn (W.D.)

* Correspondence: pengchl@scib.ac.cn

+ These authors contributed equally to this work.

check for updates

Citation: Cai, M.; Lin, X.; Peng, J.; Zhang, J.; Chen, M.; Huang, J.; Chen, L.; Sun, F.; Ding, W.; Peng, C. Why Is the Invasive Plant Sphagneticola trilobata More Resistant to High Temperature Than Its Native Congener? Int. J. Mol. Sci. 2021, 22, 748. https://doi.org/10.3390/ ijms22020748

Received: 21 December 2020 Accepted: 11 January 2021 Published: 13 January 2021

Publisher's Note: MDPI stays neutral with regard to jurisdictional clai$\mathrm{ms}$ in published maps and institutional affiliations.

Copyright: (C) 2021 by the authors. Licensee MDPI, Basel, Switzerland. This article is an open access article distributed under the terms and conditions of the Creative Commons Attribution (CC BY) license (https:// creativecommons.org/licenses/by/ $4.0 /)$.

\begin{abstract}
Climate change and invasive alien species threaten biodiversity. High temperature is a worrying ecological factor. Most responses of invasive plants aimed at coping with adversity are focused on the physiological level. To explore the molecular mechanisms underlying the response of an invasive plant (Sphagneticola trilobata L.) to high temperature, using a native species (Sphagneticola calendulacea L.) as the control, relevant indicators, including photosynthetic pigments, gas exchange, chlorophyll fluorescence, the antioxidant system, and related enzyme-coding genes were measured. The results showed that the leaves of $S$. calendulacea turned yellow, photosynthetic pigment content (Chl $a$, Chl $b$, Car, Chl) decreased, gas exchange $\left(\mathrm{P}_{\mathrm{n}}\right)$ and chlorophyll fluorescence parameters $\left(\mathrm{F}_{\mathrm{v}} / \mathrm{F}_{\mathrm{m}}, \Phi_{\mathrm{PSII}}\right)$ decreased under high temperature. It was also found that high temperature caused photoinhibition and a large amount of ROS accumulated, resulting in an increase in MDA and relative conductivity. Antioxidant enzymes (including SOD, POD, CAT, and APX) and antioxidants (including flavonoids, total phenols, and carotenoids) were decreased. The qPCR results further showed that the expression of the PsbP, PsbA, and RubiscoL, SOD, POD, CAT, and APX genes was downregulated, which was consistent with the results of physiological data. Otherwise, the resistance of $S$. trilobata to high temperature was better than that of $S$. calendulacea, which made it a superior plant in the invasion area. These results further indicated that the gradual warming of global temperature will greatly accelerate the invasion area of $S$. trilobata.
\end{abstract}

Keywords: high temperature stress; Sphagneticola; gene expression; photosynthesis

\section{Introduction}

Climate change poses potential major threats to global biodiversity and ecosystem functions. The global average temperature is expected to increase by $1.4-4.3{ }^{\circ} \mathrm{C}$ by the end of the twenty-first century [1]. Global warming and rising temperatures will cause more frequent and extremely high temperatures in many parts of the world. High temperature (HT) is a worrying ecological factor. When a plant is exposed abruptly to temperatures above the normal optimum, homeostasis in the cell is disturbed, some catalytic enzymes, gradually lose their activity, and the cell structure is damaged, resulting in plant growth reduction, changes in photosynthetic efficiency, oxidative stress, and even death under extreme conditions [2-4]. Therefore, high-temperature stress is among the main abiotic stresses limiting plant productivity.

Alien species invasion is recognized as an important part of global environmental change. Throughout the 21st century, climate change and invasive alien species have been threatening biodiversity $[5,6]$. In many cases, climate warming may facilitate the spread of 
invasive plants by increasing their growth and competitive ability [7]. Sphagneticola trilobata (L.) Pruski (Asteraceae), listed by the IUCN among the top 100 of most alien invasive species in the world, is a perennial creeping herb and native to South America [8]. It is now widely distributed in many countries and regions of Southeast Asia and the Pacific. In the 1970s, it was introduced into China as a ground cover plant and soon escaped into the wild. At present, it is widely distributed in Southeast China, coastal areas, islands, and other areas [9]. In South China, S. trilobata has been expanding continuously, showing strong tolerance ability under high temperature in summer, crowding out Sphagneticola calendulacea (L.) Pruski and forming a single dominant species, which seriously threatens the biodiversity of its indigenous congener [10]. This is closely related to its strong resistance mechanism.

Photosynthesis is the most sensitive biological process affected by high-temperature stress, and is closely related to plant metabolism and growth performance. The photosystem II (PSII) reaction center and $\mathrm{CO}_{2}$ assimilation are the main targets that are vulnerable to high temperature stress. The PSII reaction center is one of the most heat-sensitive components of the photosynthetic apparatus, and the expression of genes involved in regulation of photosynthesis will be affected by high temperature [11]. It has been found that the electron donor side of PSII is a primary damage site, and oxygen-evolving complex (OEC) activities were found to decrease under high temperature [4]. High temperature can also affect the process of carbon assimilation, by inhibiting the activities of ribulose-1,5-bisphosphate carboxylase/oxygenase (rubisco) and rubisco activase (RA) and reducing the photosynthetic rate of plants [12]. Apart from this, high temperature increases the generation of reactive oxygen species (ROS), including singlet oxygen $\left({ }_{1} \mathrm{O}^{2}\right)$, superoxide anion $\left(\mathrm{O}_{2}{ }^{-}\right)$, hydrogen peroxide $\left(\mathrm{H}_{2} \mathrm{O}_{2}\right)$, and hydroxyl radical $(\bullet \mathrm{OH})$. Various subcellular organelles including chloroplasts, mitochondria, and peroxisomes are the common sites of ROS production. The excessive production of ROS can damage enzymes, cellular proteins, DNA and RNA, eventually resulting in the death of cells [13]. Membranes are the targets of HT stress and membrane lipid composition is a crucial factor for temperature tolerance or susceptibility. HT stress causes damage to thylakoid membranes, increase lipid peroxidation, and cause membrane damage [14]. Plants have developed an efficient antioxidative system with enzymatic and non-enzymatic antioxidants, which can reduce ROS up to a certain level. These antioxidant enzymes are superoxide dismutase (SOD), catalase (CAT), peroxidase (POD), ascorbate peroxidase (APX), monodehydroascorbate reductase (MDHAR), glutathione reductase (GR), and dehydroascorbate reductase (DHAR), which are found in different organelles or subcellular compartments. Previous studies have shown that the changes in the gene expression of antioxidant enzymes may contribute to plant molecular adaptation, and maintaining a high level of antioxidant transcripts may play a key role in protecting plants from oxidative stress [15]. Zhao et al. found that the heat-acclimated plant Orchardgrass maintained high levels of gene expression encoding SOD, CAT, and POD enzymes under heat stress [16]. In addition, Flavonoids, carotenoids, ascorbate, tocopherols, phenolics, and glutathione serve as potent non-enzymatic antioxidants in plants. A previous study showed that the thermal stability of the photosynthetic apparatus of $S$. trilobata is higher than that of the S. calendulacea. On exposure to HT, S. trilobata has an effective regulatory mechanism in the energy partitioning of PSII complexes by increasing the xanthophyll-dependent thermal dissipation $\left(\Phi_{\mathrm{NPQ}}\right)$ and decreasing slightly the proportion of constitutive thermal dissipation $\left(\Phi_{\mathrm{f}, \mathrm{D}}\right)$ [10]. However, the mechanism of antioxidant activity has not been reported in depth. Many researchers have focused on the physiological level of two Sphagneticola species under adverse conditions $[17,18]$. Nevertheless, the expression patterns of genes involved in photosynthesis and antioxidant systems in response to adversity is not clear. Thus, we compared the antioxidant activity, photosynthetic and gene expression patterns of two Sphagneticola species under high temperature. The insights from this study will help us further study the molecular mechanism of thermoregulation of S. trilobata. 


\section{Results}

\subsection{Changes in Plant Appearance and Photosynthetic Pigments under HT Treatment}

After 22 days of treatment, we observed that the leaves of S. trilobata exposed to HT were greener than those of the control group $\left(25 \pm 1^{\circ} \mathrm{C}\right)$. In contrast, $S$. calendulacea leaves exhibited an obvious yellow color under HT treatment, especially in the leaf base region (Figure 1A). Compared with the control group, different trends were observed in the variations in photosynthetic pigments in the two Sphagneticola species under HT treatment. The chlorophyll $a(\mathrm{Chl} a)$, chlorophyll $b(\mathrm{Chl} b)$, total chlorophyll (Chl), carotenoids (Car), and chlorophyll $a / b(\mathrm{Chl} a / b)$ in the leaves of $S$. trilobata exposed to HT were all increased, while they decreased significantly in the leaves of $S$. calendulacea $(p<0.01)$, coinciding with the leaf appearance (Figure 1B-F).

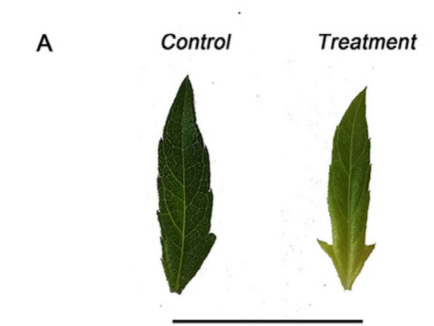

S. calendulacea
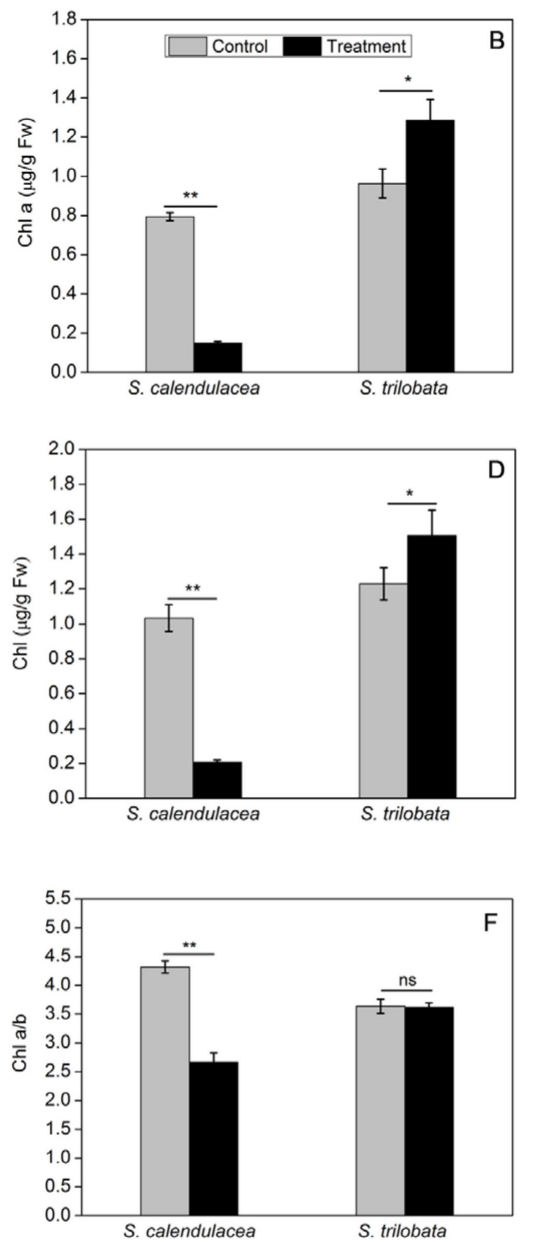

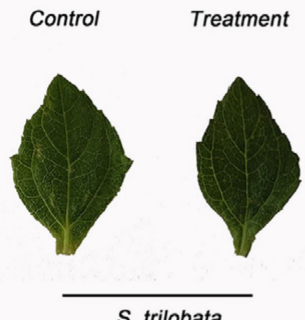

S. trilobata
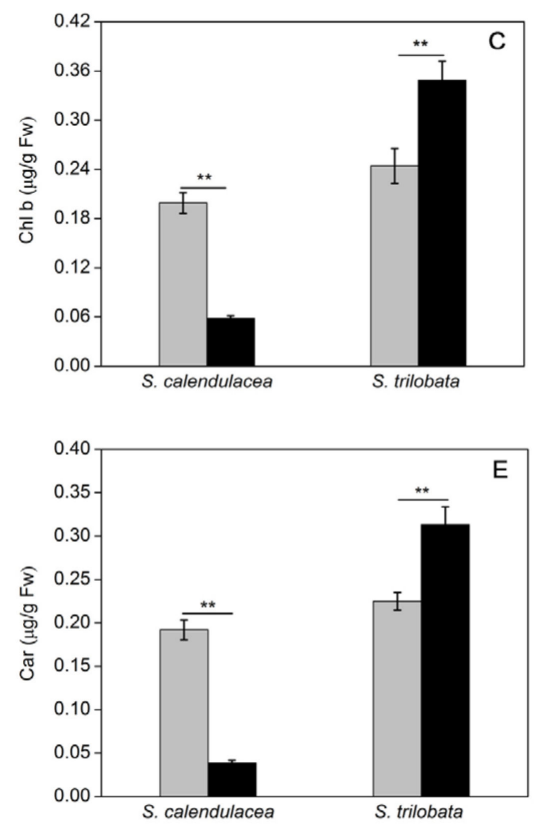

Figure 1. Effect on appearance (A), Chl $a(\mathbf{B}), \mathrm{Chl} b(\mathbf{C}), \mathrm{Chl}$ (D), Car (E) content and Chl a/ $b$ (F) in two Sphagneticola species under HT treatment $\left(35 \pm 1{ }^{\circ} \mathrm{C}\right)$. The data represent the mean $\pm \mathrm{SE}$ $(n=5)$. Asterisks above columns indicate statistical significance for comparisons between $\mathrm{HT}$ and room temperature. $\left({ }^{* *} p<0.01\right.$ and $\left.{ }^{*} p<0.05\right)$. 


\subsection{Changes in Photosynthetic Capacity under HT Treatment}

Under HT treatment, we found that there was a significant decrease reduction of $42.2 \%$ in net photosynthetic rate $\left(\mathrm{P}_{\mathrm{n}}\right)$ values of $S$. calendulacea $(p<0.05)$. However, no significant differences were observed in the $P_{n}$ values of $S$. trilobata (Figure 2A). The photosynthetic efficiency of plants is closely related to the electron transfer of chloroplasts. With respect to the control treatment, we found that S. calendulacea and S. trilobata showed decreases in maximum photochemical efficiency of PSII $\left(\mathrm{F}_{\mathrm{v}} / \mathrm{F}_{\mathrm{m}}\right)$ of $48.5 \%$ and $1.4 \%$ under HT treatment, respectively (Figure 2B). We also observed that the operational photochemical efficiency $\left(\Phi_{\mathrm{PSII}}\right)$ increased in $S$. trilobata but was significantly inhibited in S. calendulaceas with a decrease range of $24.6 \%$ during the exposure to high temperature (Figure $2 \mathrm{C}$ ).
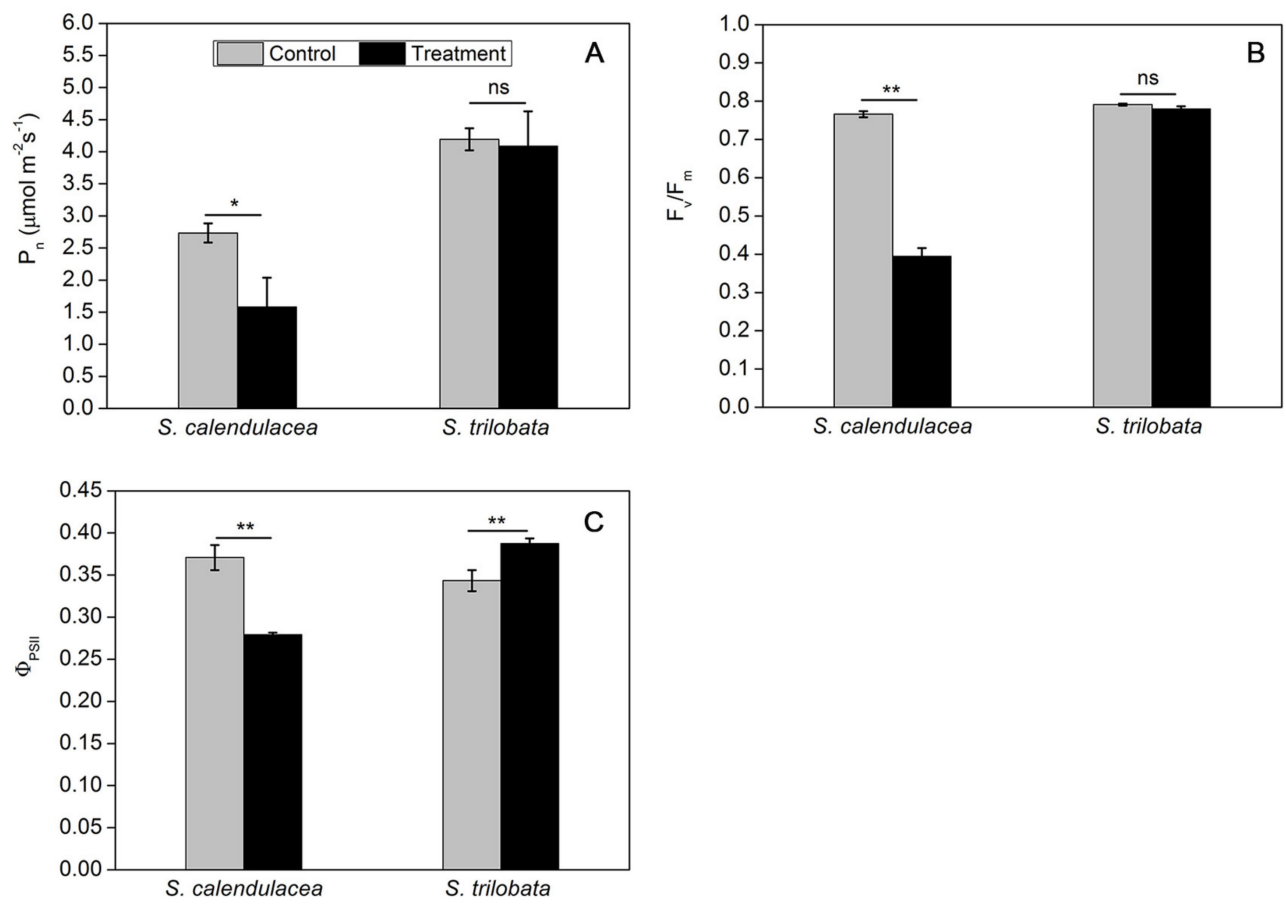

Figure 2. Effect on $P_{\mathrm{n}}(\mathbf{A}), \mathrm{F}_{\mathrm{V}} / \mathrm{F}_{\mathrm{m}}(\mathbf{B})$, and $\Phi_{\mathrm{PSII}}(\mathbf{C})$ in two Sphagneticola species under HT treatment $\left(35 \pm 1^{\circ} \mathrm{C}\right)$. The data represent the mean $\pm \mathrm{SE}(n=5)$. Asterisks above columns indicate statistical significance for comparisons between HT and room temperature. $\left({ }^{* *} p<0.01\right.$ and $\left.{ }^{*} p<0.05\right)$.

\subsection{Changes in Reactive Oxygen Species (ROS) and Cellular Membrane Stability under HT Treatment}

Generally, ROS are produced in cell under a variety of environmental stress conditions, which can lead to oxidative stress in plants. The histochemical staining results showed that $\mathrm{H}_{2} \mathrm{O}_{2}$ accumulated in the leaves of the $\mathrm{S}$. calendulacea was more than that of $S$. trilobata under HT treatment, and was mainly distributed at the leaf base region (Figure $3 \mathrm{~A}$ ). The $\mathrm{H}_{2} \mathrm{O}_{2}$ content in two Sphagneticola species was further quantified using a colorimetric assay. We found that $\mathrm{H}_{2} \mathrm{O}_{2}$ content was also significantly increased in $S$. calendulacea $(p<0.05)$ while slightly increased in S. trilobata (Figure 3B). The malondialdehyde (MDA) content of the two Sphagneticola species increased upon exposure to high temperature, and the change ranges of S. trilobata (15.9\%) was much smaller than that of S. calendulacea (134.5\%) (Figure 3C). It was also found that the membrane leakage rate increased in S. calendulacea by $29.8 \%$, whereas there was no significant difference in the leaves of $S$. trilobata (Figure 3D). 
A
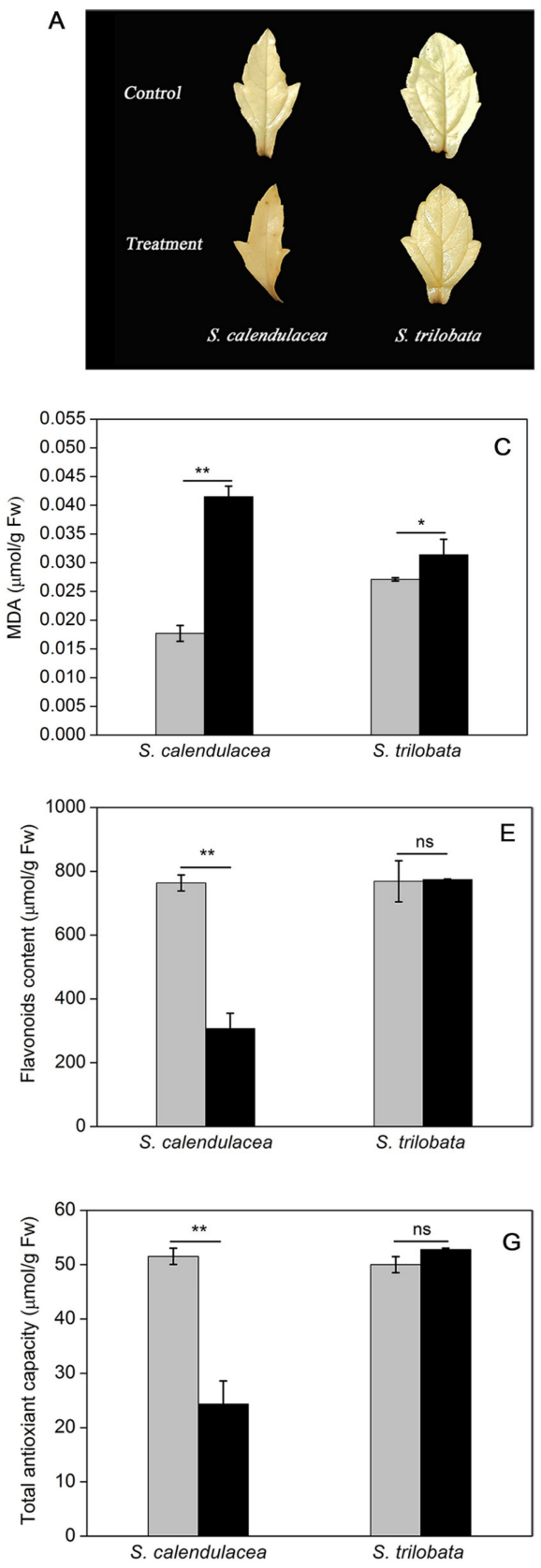
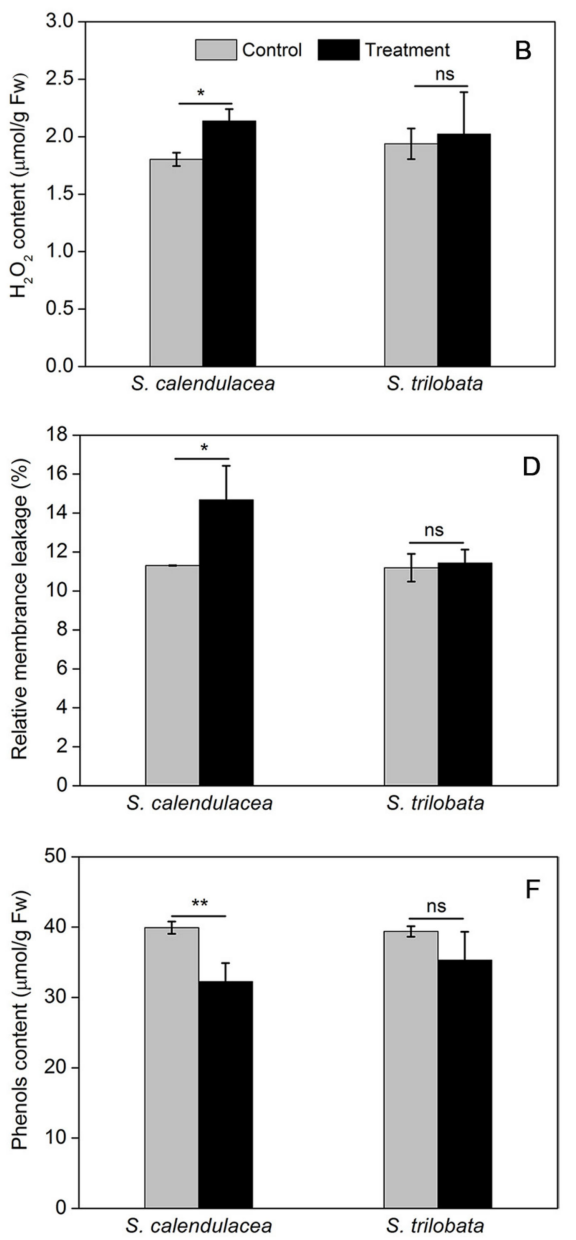

Figure 3. Results of $\mathrm{H}_{2} \mathrm{O}_{2}$ histochemical staining (A), $\mathrm{H}_{2} \mathrm{O}_{2}$ content (B), MDA content (C), membrane leakage rate (D) and non-enzymatic antioxidants, including flavonoids (E), total phenols (F) and TAC $(\mathbf{G})$, in two Sphagneticola species under HT treatment $\left(35 \pm 1{ }^{\circ} \mathrm{C}\right)$. The data represent the mean $\pm \mathrm{SE}(n=5)$. Asterisks above columns indicate statistical significance for comparisons between HT and room temperature $\left(* * p<0.01\right.$ and $\left.{ }^{*} p<0.05\right)$.

\subsection{Changes in Non-Enzymatic Antioxidant Content and Antioxidant Enzyme Activity under HT Treatment}

Flavonoids and total phenols are antioxidants that exist in plants to scavenge ROS, and the total antioxidant capacity (TAC) of leaves is the comprehensive performance of the main antioxidant substances in the leaves. The results showed that, compared with the control treatment, no significant differences in the values of flavonoids, total phenols or TAC were observed for S. trilobata under HT treatment. However, S. calendulacea showed decreased flavonoids, total phenols, and TAC values of $59.8 \%, 19.2 \%$, and $52.8 \%$, respectively (Figure 3E-G). 
Moreover, we observed that SOD, POD, and CAT activities of $S$. trilobata did not change under HT treatment, but all of them were greatly reduced in S. calendulacea with change ranges of $64.2 \%, 68.9 \%$, and $30.3 \%$, respectively (Figure $4 \mathrm{~A}-\mathrm{C}$ ). Unlike SOD, POD, and CAT, the decreased activity of APX was obtained in two Sphagneticola species under HT treatment, whereas the decreased range of $S$. trilobata $(26.3 \%)$ was much smaller than that of S. calendulacea (34.5\%) (Figure 4D). These results are in agreement with the previous reports regarding the changes in non-enzymatic antioxidants content under HT treatment.
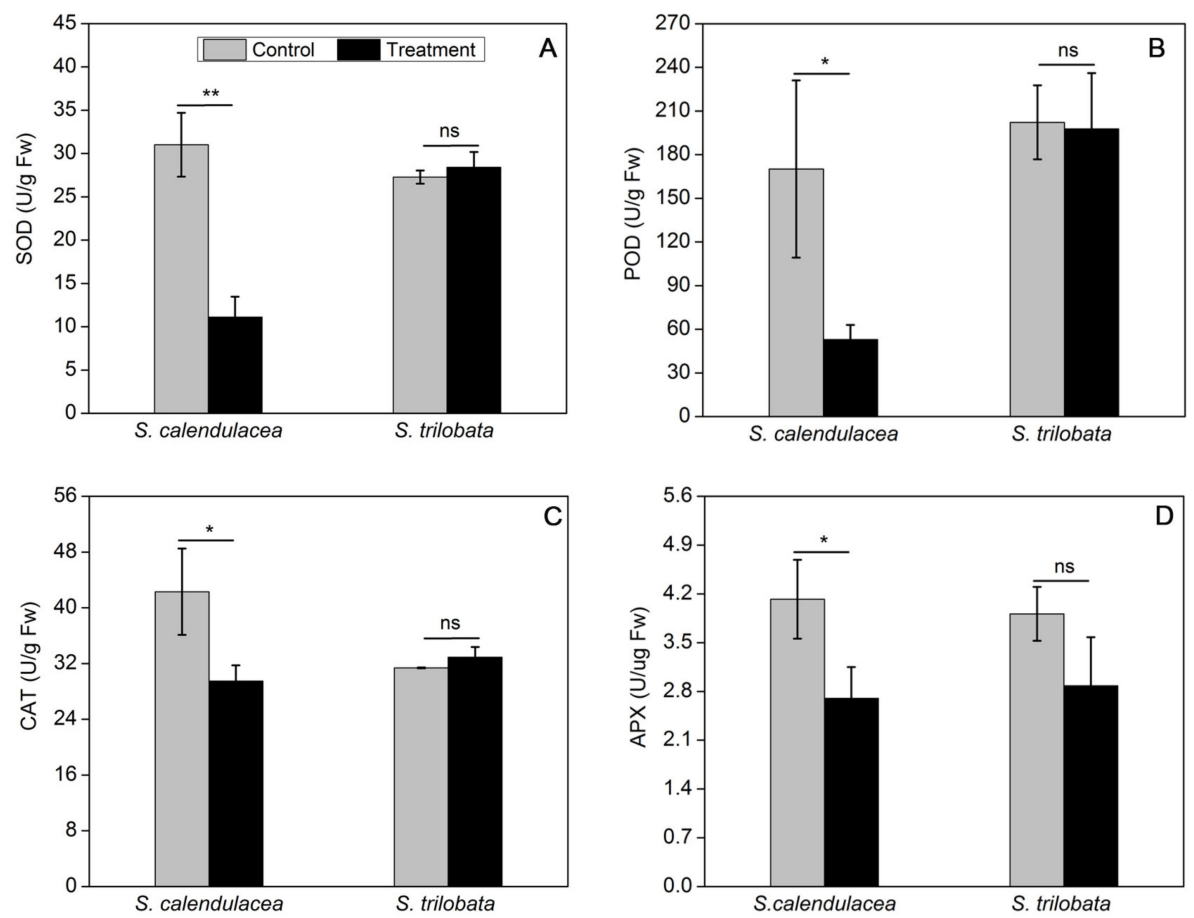

Figure 4. Effect on antioxidant enzyme activities including SOD (A), POD (B), CAT (C), and APX (D) in two Sphagneticola species under HT treatment $\left(35 \pm 1^{\circ} \mathrm{C}\right)$. The data represent the mean $\pm \mathrm{SE}$ $(n=5)$. Asterisks above columns indicate statistical significance for comparisons between HT and room temperature. ${ }^{* *} p<0.01$ and $\left.{ }^{*} p<0.05\right)$.

2.5. Changes in the Expression of Genes Encoding Photosynthesis and Antioxidant Enzymes under HT Treatment

The expression of genes encoding photosynthesis and antioxidant enzymes was measured by the method of qRT-PCR. The results showed that the expression levels of photosynthesis-related genes, including $P s b P, P s b A$, and Rubisco L, were slightly increased in S. trilobata under HT treatment, but there were no significant differences in all of them. In contrast, the transcript levels of photosynthesis-related genes decreased by 1.6-7-fold in S. calendulacea under HT treatment (Figure 5A-C). The expression pattern of antioxidant enzyme-related genes was similar to that of photosynthesis-related genes. Therefore, SOD, POD, CAT, and APX gene expression levels were also not significantly different in S. trilobata, while these levels were all decreased in S. calendulacea and the expression of CAT was most obviously decreased by approximately 27.0 -fold under HT treatment compared to the control treatment (Figure 5D-G). The expression of these key enzyme genes at the transcription level was consistent with a previous report related to photosynthetic capacity (Figure 2A) and antioxidant enzyme activity (Figure 4). 

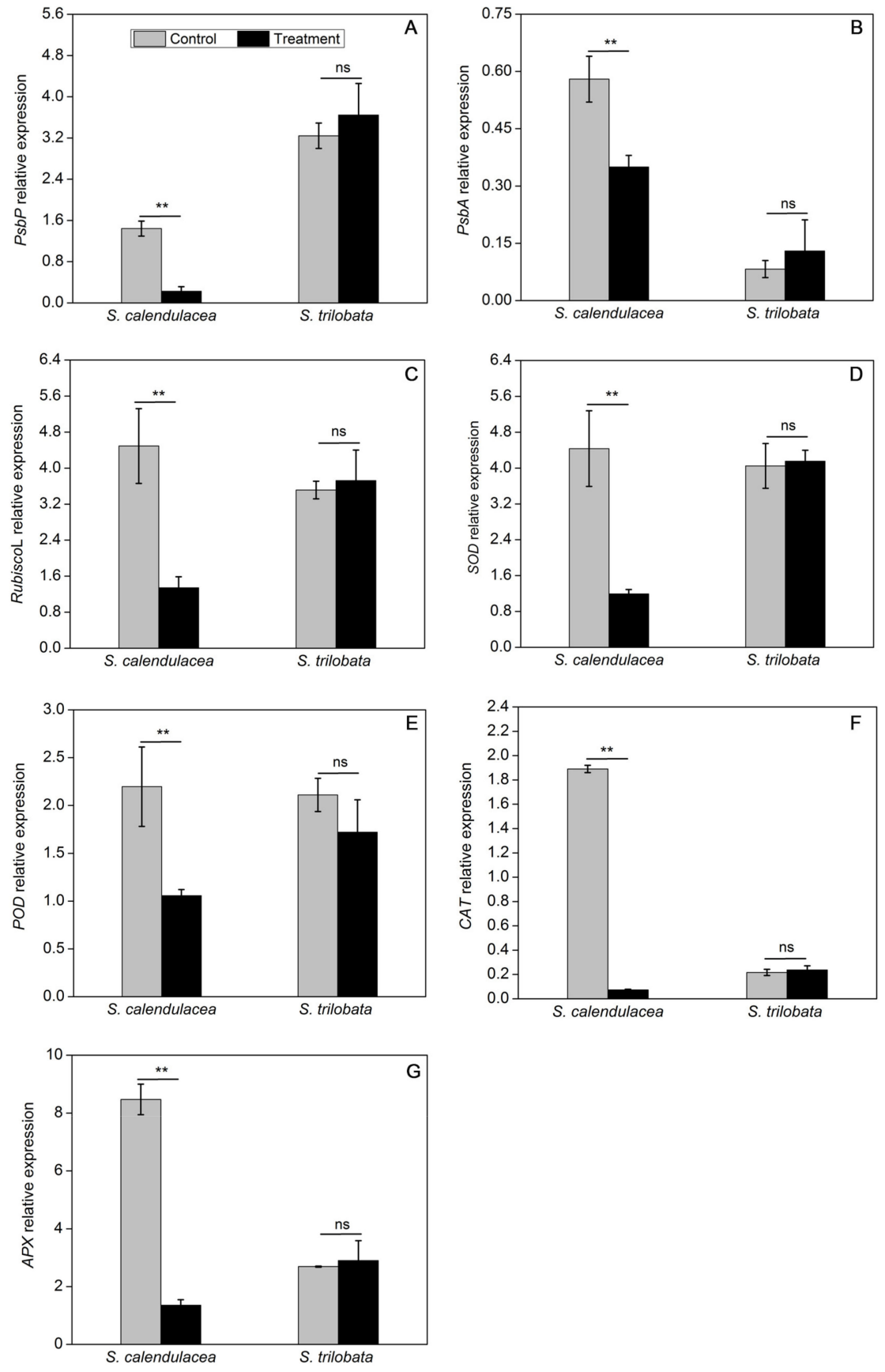

Figure 5. Effect on relative expression levels of photosynthesis-related genes, including PsbP (A), PsbA (B), RubiscoL (C), and antioxidant enzyme-related genes, including SOD (D), POD (E), CAT (F), and $A P X(\mathbf{G})$ in two Sphagneticola species under HT treatment $\left(35 \pm 1^{\circ} \mathrm{C}\right)$. The data represent the mean $\pm \mathrm{SE}(n=5)$. Asterisks above columns indicate statistical significance for comparisons between HT and room temperature. $\left({ }^{* *} p<0.01\right)$.

\section{Discussion}

Photosynthesis is considered to be the most important photochemical reaction in plants and is highly sensitive to temperature. In this study, the expression of genes in the photosynthesis pathway of $S$. trilobata were not significantly different under HT stress. Conversely, $P s b A$ and $P s b P$ gene expression in the leaves of $S$. calendulacea was significantly decreased under HT stress (Figure 5A,B). A low level of PsbA gene expression has been shown to negatively influence the D1 content in PSII [19] and decrease the photosynthesis capability [20]. The OEC protein is encoded by the PsbP gene, and its damage will also 
inevitably affect the heat tolerance of PSII under HT stress [21]. HT stress further inhibited the electron transfer from the OEC protein to the PSII acceptor side [22]. The result of this study showed that $\mathrm{F}_{\mathrm{v}} / \mathrm{F}_{\mathrm{m}}$ and $\Phi_{\mathrm{PSII}}$ in $S$. trilobata were close to or even slightly higher than normal temperature, while all of them were significantly decreases in S. calendulacea (Figure 2B,C). It was suggested that compared with S. trilobata, the leaves of S. calendulacea were the most seriously damaged under HT stress. Similar results were also found in tomato seedlings [23]. Studies have shown that the capacity for ribulose-1,5-diphosphate $(\mathrm{RuBP})$ regeneration could be dramatically inhibited by the disruption of electron transfer and the inactivation of the OEC enzyme [24,25]. The RT-qPCR results demonstrated that the RubiscoL gene expression was significantly decreased in S. calendulacea under HT stress (Figure 5C), thus limiting the rate of $\mathrm{CO}_{2}$ fixation [12]. This is in accordance with the results of $\mathrm{P}_{\mathrm{n}}$ (Figure 2A). Liu et al. have found that lower quantities of the photosynthetic pigments may inhibit the photosynthetic capacity [26]. The results showed that HT stress reduced Chl contents in the leaves of S. calendulacea (Figure 1B-F) and limited the absorption of light energy [27]. Particularly, there was a significant increase in the photosynthetic pigment content in S. trilobata and its leaves remained green, indicating the photosynthetic capacity of $S$. trilobata was basically not affected by HT stress. These results are consistent with Song et al. [10].

It has been seen that HT increases the generation of ROS [28]. The results of this study showed that there was no accumulation of ROS in S. trilobata at HT, while the situation in S. calendulacea was contrary (Figure 3A,B). Some studies have shown that ROS accumulate in plants under stress and attack unsaturated fatty acids in cells, aggravate membrane peroxidation, and lead to membrane system damage and cell damage [29]. The MDA content and relative conductivity of $S$. calendulacea both increased significantly under HT stress, while MDA content in $S$. trilobata increased slightly, and its relative conductivity was not significantly increased compared with the normal temperature (Figure 3C,D). These results suggested that compared with $S$. calendulacea, S. trilobata was less injured, and the cell membrane stability was stronger under HT stress. Maintenance of membrane integrity is a major mechanism by which plants cope with HT stress [30]. Furthermore, some studies have also shown that excessive accumulation of ROS can bleach photosynthetic pigments, affecting the absorption of light energy [31,32], which could explain the significant reduction in chlorophyll content of $S$. calendulacea leaves and the phenomenon of yellowing under HT stress (Figure 1A).

To protect plants from oxidative stress and maintain normal cell function, antioxidant enzymes including SOD, POD, CAT, and APX, play the role of ROS scavengers in plants. We can further understand the molecular adaptation of plants to HT stress by studying the gene expression underlying the change in antioxidant enzyme activity. The results indicated that the SOD, POD, CAT, and APX genes of $S$. calendulacea showed low expression at the transcription level (Figure 5D-G), and the antioxidant enzyme activity was also decreased under HT stress (Figure 4A-D). Studies have demonstrated that various environmental stresses lead to $\mathrm{H}_{2} \mathrm{O}_{2}$ production, and its excessive production causes the regulation of POD, CAT, and APX genes expression [33]. It has also been found that a decrease in CAT and APX activity will greatly weaken the protective effect of the antioxidant system, resulting in an increase in the active oxygen concentration [34]. The decrease in CAT and POD enzyme activities could not timely convert $\mathrm{H}_{2} \mathrm{O}_{2}$ into $\mathrm{H}_{2} \mathrm{O}$ and $\mathrm{O}_{2}$ that was harmless to cells. In contrast, under HT treatment, the antioxidant enzyme gene expression and its regulated enzyme activity of $S$. trilobata remained at a high levels as observed under normal temperature, which was an important reason for its stronger ROS-scavenging ability. In addition, non-enzymatic antioxidants including flavonoids (Figure 3E), total phenols content (Figure 3F), and TAC (Figure 3G) decreased significantly, indicating that scavenging capacity of ROS was much lower than that of $S$. trilobata. Moreover, carotenoid content increased in S. trilobata but decreased significantly in S. calendulacea under HT stress (Figure 1E). Studies have found that carotenoids could act as endogenous antioxidants of cells, absorbing residual energy, quenching active oxygen, and preventing membrane 
peroxidation [35]. Therefore, the destruction of the antioxidant system, which failed to remove ROS in a timely manner, was the main reason that the degree of oxidative stress in S. calendulacea is more serious than that of in S. trilobata.

In summary, as a heat-sensitive plant, the ability of $S$. calendulacea to resist HT stress in South China was far lower than that of $S$. trilobata. The main reason was the difference of photosynthesis in response to HT stress (Figure 6). The resistance of S. trilobata to cope with HT stress was better than that of S. calendulacea, which made it a single superior population in the invasion area. These results further indicated that the gradual warming of global temperature will greatly accelerate the invasion area of $S$. trilobata.

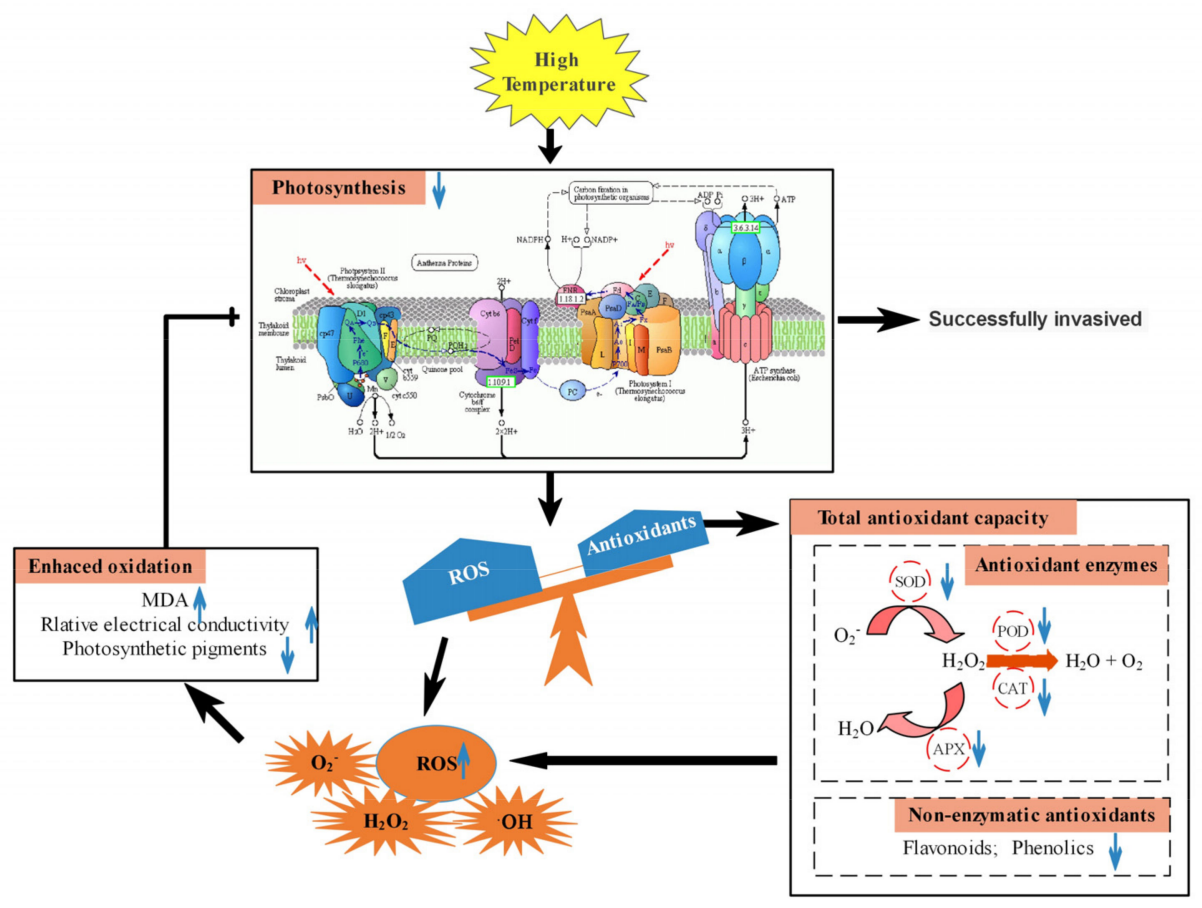

Figure 6. Photosynthetic response of two Sphagneticola species under HT stress. HT inhibited the expression of key PSII genes including PsbP, PsbA, and RubiscoL, decreased $\mathrm{F}_{\mathrm{v}} / \mathrm{F}_{\mathrm{m}}$ and $\Phi_{\mathrm{PSII}}$, and greatly reduced the photosynthetic capacity of $S$. calendulacea. High temperature results in light inhibition, which leads to the accumulation of ROS. However, the scavenging ability of the enzymatic and non-enzymatic antioxidant systems of $S$. calendulacea was decreased and ROS could not be removed in time. On the one hand, the decreased antioxidant enzyme activity was due to the down-regulation of $S O D, P O D, C A T$, and $A P X$ genes expression. On the other hand, the antioxidants contents including flavonoids, total phenols, and carotenoids were also decreased. This accumulation of ROS further caused an increase in MDA and relative conductivity, thus increasing the degree of membrane peroxidation and pigment bleaching in photosynthetic organs. However, the resistance of S. trilobata to cope with HT stress was better than that of S. calendulacea.

\section{Materials and Methods}

\subsection{Plant Materials, Cultivation, and HT Treatment}

Sphagneticola trilobata and Sphagneticola calendulacea were collected from the campus of South China Normal University (Guangzhou, China). The experimental plant materials were propagated from segments that had two stem nodes. After rooting and growing $2-3$ young leaves, the segments were transplanted into pots. One plant of each kind per pot was cultured using hydroponics in a greenhouse under natural light conditions, with a temperature of $25 \pm 1{ }^{\circ} \mathrm{C}, 50-70 \%$ relative humidity, and a $12 \mathrm{~h}$ photoperiod. After one month of growth, uniform seedlings with the same size and height were selected for study. One half of the materials were randomly selected for HT treatment $\left(35 \pm 1^{\circ} \mathrm{C}\right)$. Materials grown at room temperature $\left(25 \pm 1{ }^{\circ} \mathrm{C}\right)$ were used as the control group. Control and 
treatment groups were set for each species of Sphagneticola. After 22 days of HT treatment, the phenotype was recorded and the relevant physiological indexes were measured.

\subsection{Gas Exchange and Chlorophyll Fluorescence Measurements}

Gas exchange was measured using the Li-6400 portable photosynthesis system (LICOR, Inc., Lincoln, NE, USA). Before the measurement, the leaves were acclimated for $5-10 \mathrm{~min}$ at a photosynthetic active radiation (PAR) of $800 \mu \mathrm{mol} \mathrm{m} \mathrm{m}^{-2}$ and a $\mathrm{CO}_{2}$ concentration was maintained at $400 \mu \mathrm{mol} \mathrm{mol}^{-1}$ in this study. Once the steady-state gas exchange rates were observed at these conditions, the instrument automatically calculates and records the net photosynthetic rate $\left(\mathrm{P}_{\mathrm{n}}\right)$.

The chlorophyll fluorescence parameters were tested by a chlorophyll fluorescence imaging system (CF imager, Technical Ltd., Colchester, UK). Before each test of the minimum fluorescence $\left(\mathrm{F}_{\mathrm{o}}\right)$ and maximum fluorescence $\left(\mathrm{F}_{\mathrm{m}}\right)$, the leaves were dark-adapted for $20 \mathrm{~min}$. The maximum quantum yield $\left(\mathrm{F}_{\mathrm{v}} / \mathrm{F}_{\mathrm{m}}\right)$ of PSII photochemistry was calculated using the following formula: $\left(\mathrm{F}_{\mathrm{m}}-\mathrm{F}_{\mathrm{o}}\right) / \mathrm{F}_{\mathrm{m}}$. The steady-state fluorescence $\left(\mathrm{F}_{\mathrm{s}}\right)$ and the maximum fluorescence $\left(\mathrm{F}_{\mathrm{m}}{ }^{\prime}\right)$ in the light-adapted state were measured at $800 \mu \mathrm{mol} \mathrm{m}^{-2} \mathrm{~s}^{-1}$ PPFD. The actual photochemical efficiency $\left(\Phi_{\mathrm{PSII}}\right)$ was calculated as $\Phi_{\mathrm{PSII}}=\left(\mathrm{F}_{\mathrm{m}}{ }^{\prime}-\mathrm{F}_{\mathrm{s}}\right) / \mathrm{F}_{\mathrm{m}}{ }^{\prime}$.

\subsection{Chlorophyll Content Determination}

Leaves $(0.05 \mathrm{~g})$ were ground with liquid nitrogen in a $10 \mathrm{~mL}$ centrifugal tube and extracted in $4 \mathrm{~mL}$ of $80 \%$ acetone at $4{ }^{\circ} \mathrm{C}$ in the dark overnight. With $80 \%$ acetone as the blank control, the absorbance of supernatant was measured by a UV-Vis 2450 spectrophotometer (Shimadzu, Kyoto, Japan) at wavelengths of $663 \mathrm{~nm}$ and $645 \mathrm{~nm}$. According to Wellburn [36], chlorophyll and carotenoid contents were calculated.

\subsection{Hydrogen Peroxide $\left(\mathrm{H}_{2} \mathrm{O}_{2}\right)$ Histochemical Staining and $\mathrm{H}_{2} \mathrm{O}_{2}$ Content Measurements}

$3,3^{\prime}$-Diaminobenzidine (DAB) staining was used to detect the production of $\mathrm{H}_{2} \mathrm{O}_{2}$ in situ. Fresh leaves were infiltrated with $50 \mathrm{mM}$ potassium phosphate buffer $(\mathrm{pH} 7.0)$ containing $0.5 \mathrm{mg} \mathrm{mL}^{-1} \mathrm{DAB}$ and exposed to a vacuum for $20 \mathrm{~min}$. After incubation for $2 \mathrm{~h}$ in the dark, 95\% (v/v) ethanol was used to eliminate the chlorophyll in the leaves.

Fresh leaves $(0.1 \mathrm{~g})$ were weighed and homogenized in cold with $1 \mathrm{~mL}$ phosphate buffered saline (50 mM, pH7.0). The homogenate was subsequently centrifuged at $4000 \mathrm{rpm}$ for 15 min at $4{ }^{\circ} \mathrm{C}$. The determination $\mathrm{H}_{2} \mathrm{O}_{2}$ content was measured according to the instructions of the kit (Shenzhen Ziker Biological Technology Co., Ltd., Shenzhen, Guangdong, China). The absorbance of the sample was determined at a wavelength of $450 \mathrm{~nm}$ with a multimode plate reader (EnSpire, PerkinElmer, Waltham, MA, USA).

\subsection{Cell Membrane Leakage Rate and Malondialdehyde (MDA) Content Analysis}

Cell membrane leakage was measured by a DDS-11C conductometer (Shanghai Dapu Instruments) as described by Zheng et al., with minor modifications [37]. Three 0.8-cmdiameter leaf discs were incubated in $5 \mathrm{~mL}$ of distilled water for $3 \mathrm{~h}$. Then, the samples were boiled for $30 \mathrm{~min}$. The cell membrane leakage rate was calculated according to the formula: $(\mathrm{R} 1 / \mathrm{R} 2) \times 100 \%$, where R1 and R2 are the initial conductivity and electrolyte conductivity, respectively.

Malondialdehyde (MDA) was determined using the thiobarbituric acid (TBA) method. Leaf samples $(0.1 \mathrm{~g})$ were ground in $2 \mathrm{~mL}$ of $0.1 \%(w / v)$ trichloroacetic acid (TCA) solution, and the homogenate was centrifuged. Total of $1 \mathrm{~mL}$ of supernatant was reacted with an equal volume of $0.67 \%(w / v)$ thiobarbituric acid (TBA) in a boiling water bath for $30 \mathrm{~min}$. The absorbance of the mixture was measured at 600,532 , and $450 \mathrm{~nm}$ wavelengths by a UV-Vis 2450 spectrophotometer. According to the formula of Wang and Jin [38], the MDA content was calculated. 


\subsection{Enzymatic and Non-Enzymatic Antioxidants Determination}

Flavonoid, total phenol, and total antioxidant capacity (TAC) were extracted from $0.1 \mathrm{~g}$ of leaves in $2 \mathrm{~mL}$ of $95 \%(v / v)$ methanol at $4{ }^{\circ} \mathrm{C}$ for $24 \mathrm{~h}$. Briefly, flavonoid content was measured as described by the modified method of Park et al. [39]. The reaction mixture contained $2 \mathrm{~mL}$ of 8 -fold diluted extract, $200 \mu \mathrm{L}$ of $5 \% \mathrm{NaNO}_{2}, 300 \mu \mathrm{L}$ of $10 \% \mathrm{AlCl}_{3}$, and $1 \mathrm{~mL}$ of $1 \mathrm{M} \mathrm{NaOH}$. The absorbance of the mixture at $510 \mathrm{~nm}$ was determined by using a spectrophotometer. According to Cheung et al. [40], the total phenolic content of the extracts was measured following the method of Folin-Ciocalteu at a wavelength of $765 \mathrm{~nm}$. $1 \mathrm{~mL} \mathrm{10 \%} \mathrm{Folin-Ciocalteu} \mathrm{Reagent} \mathrm{and} 2 \mathrm{~mL}$ of $0.7 \mathrm{M} \mathrm{Na}_{2} \mathrm{CO}_{3}$ were mixed with $1 \mathrm{~mL}$ of extract. Total antioxidant capacity was assayed in a reaction solution consisting of $150 \mu \mathrm{L}$ of extracts and $3 \mathrm{~mL}$ of $120 \mathrm{mM}$ DPPH solution [41]. The absorbance at $517 \mathrm{~nm}$ was determined after the mixture was incubated in the dark for $20 \mathrm{~min}$.

Enzymatic antioxidants including SOD, POD, CAT, and APX were determined according to the methods of Tan et al. [42], Du et al. [43], Jiang et al. [44], and Nakano and Asada [45], respectively, with slight modifications. SOD activity was measured by examining its ability to inhibit the photoreduction of nitro blue tetrazolium (NBT). Each $3 \mathrm{~mL}$ assay mixture contained: phosphate buffer ( $50 \mathrm{mM}$; pH 7.8), $20 \mu \mathrm{M}$ riboflavin, $130 \mathrm{mM}$ methionine, $0.1 \mu \mathrm{M}$ EDTA, $750 \mathrm{mM}$ NBT, and $100 \mu \mathrm{L}$ of enzyme extract. The absorbance of the samples was recorded at a wavelength of $560 \mathrm{~nm}$. The reaction solution for POD activity comprised phosphate buffer $\left(50 \mathrm{mM}\right.$, pH 7.0), $30 \mathrm{mM} \mathrm{H}_{2} \mathrm{O}_{2}$, guaiacol, and $100 \mu \mathrm{L}$ of enzyme extract. The enzyme activity was estimated by recording the increase in absorbance at $470 \mathrm{~nm}$ every $15 \mathrm{~s}$ for $3 \mathrm{~min}$. The CAT activity was measured by catalyzing the breakdown of $\mathrm{H}_{2} \mathrm{O}_{2}$ at $240 \mathrm{~nm}$ during $2 \mathrm{~min}$. A final volume of $3 \mathrm{~mL}$ of assay mixture included $30 \mathrm{mM} \mathrm{H}_{2} \mathrm{O}_{2}$ and $100 \mu \mathrm{L}$ of enzyme extract. For the estimation of APX activity, reaction ingredients were composed of $50 \mathrm{mM}$ phosphate buffer ( $\mathrm{pH}$ 7.0), $0.1 \mathrm{mM}$ EDTA, $5 \mathrm{mM}$ AsA, and $20 \mathrm{mM} \mathrm{H}_{2} \mathrm{O}_{2}$. Subsequently, the reaction was started after which $100 \mu \mathrm{L}$ of enzyme extract was added, and the change in absorbance at $290 \mathrm{~nm}$ was recorded for $1 \mathrm{~min}$.

\subsection{Gene Expression Analysis}

Total RNA was extracted using TRIzol reagent (Invitrogen, California, MA, USA) following the manufacturer's protocol. Complementary DNA (cDNA) was synthesized using a PrimeScript RT reagent kit (TaKaRa, Shiga, Japan)). Quantitative reverse transcription polymerase chain reaction (qRT-PCR) analysis was achieved by a Bio-Rad CFX96 Real-Time PCR System (CFX96, Bio-Rad, California, USA) using a SYBR Premix Ex Taq ${ }^{\mathrm{TM}}$ II Kit (Takara, Tokyo, Japan). The cycle conditions consisted of initial denaturation at $95{ }^{\circ} \mathrm{C}$ for $30 \mathrm{~s}$, followed by 39 cycles at $95^{\circ} \mathrm{C}$ for $5 \mathrm{~s}$ and $60^{\circ} \mathrm{C}$ for $34 \mathrm{~s}$, and a final melt-curve of $65-95{ }^{\circ} \mathrm{C}$. The analysis of gene expression levels was conducted by the $2^{-\Delta \Delta \mathrm{Ct}}$ method [46]. The glyceraldehyde-3-phosphate dehydrogenase $(G A P D H)$ gene was used as an internal reference gene in this study. The primers for each gene used for qRT-PCR assays are presented in Table 1.

Table 1. Primer sequences of internal and target genes.

\begin{tabular}{|c|c|}
\hline Gene Name & Primer Sequence \\
\hline \multirow{2}{*}{ GAPDH } & Forward: 5'-CTGCTTCATTCAACATC-3' \\
\hline & Reverse: 5'-CTCACGGTCAGATCAACA-3' \\
\hline \multirow[b]{2}{*}{ PsbP } & Forward: 5'-TGCAGCAAGGGATAAGGATGT-3' \\
\hline & Reverse: 5'-ACAAATGAAAGAGCATGAACAAAGA-3' \\
\hline \multirow{2}{*}{$P s b A$} & Forward: 5'-TGGAGGAGCAGCAATGA-3' \\
\hline & Reverse: 5'-GCGAAAGCGAAAGCCTA-3' \\
\hline \multirow{2}{*}{ RubiscoL } & Forward: 5'-CGGTCTCTCCAGCGCATAAA-3' \\
\hline & Reverse: 5'-CGCCTCACGGTATCCAAGTT-3' \\
\hline \multirow{2}{*}{$S O D$} & Forward: 5'-TGGTTTGAAAGCGGTGG-3' \\
\hline & Reverse: 5'-CTGGTTTAAGCCCTGTGAT-3' \\
\hline
\end{tabular}


Table 1. Cont.

\begin{tabular}{|c|c|}
\hline Gene Name & Primer Sequence \\
\hline \multirow{2}{*}{$P O D$} & Forward: 5'-CAACACCGCAGAGAAAGACT-3' \\
\hline & Reverse: 5'-CTGGGAGGTAAAGAGAAC-3' \\
\hline \multirow{2}{*}{$C A T$} & Forward: 5'-CAAGACCTGGCCTGAG-3' \\
\hline & Reverse: 5'-TGTCTCTGAGTGTCCG-3' \\
\hline \multirow{2}{*}{$A P X$} & Forward: 5'-CTAAGGAAGGCAGACTC-3' \\
\hline & Reverse: 5'-CCTGATCTATCTGCATGTG-3' \\
\hline
\end{tabular}

\subsection{Statistical Analysis}

In this experiment, all of the measurements are shown as the means \pm standard errors (SEs) of at least three biological replicates. Data were evaluated by one-way analysis of variance (ANOVA) by using IBM SPSS ${ }^{\circledR}$ Statistics (Version 19.0, IBM Corporation, New York, NY, USA). Two-tailed Student's $t$-test was used to compare the response of two Sphagneticola species under HT treatments. Differences between groups were considered statistically significant if the $p$ value was less than $0.05(p<0.05)$. OriginPro (Version 8.0, OriginLab Corporation, Northampton, MA, USA) and Adobe Photoshop CC (Version 2014, Adobe Systems, San Jose, CA, USA) software were used for regression analyses and image processing, respectively.

Author Contributions: Data curation, M.C. (Minling Cai); formal analysis, J.H. and L.C.; funding acquisition, C.P.; investigation, X.L. and J.P.; methodology, W.D. and F.S.; project administration, C.P.; resources, X.L., J.P., and J.Z.; writing—original draft, M.C. (Minling Cai); writing—review and editing, M.C. (Minghao Chen). All authors have read and agreed to the published version of the manuscript.

Funding: This work was funded by the National Natural Science Foundation of China (31870374, 41907023).

Conflicts of Interest: The authors declare no conflict of interest.

\section{References}

1. Schellnhuber, H.J. Global warming: Stop worrying, start panicking? Proc. Natl. Acad. Sci. USA 2008, 105, 14239-14240. [CrossRef]

2. Ruelland, E.; Zachowski, A. How plants sense temperature. Environ. Exp. Bot. 2010, 69, 225-232. [CrossRef]

3. Hasanuzzaman, M.; Nahar, K.; Alam, M.; Roychowdhury, R.; Fujita, M. Physiological, Biochemical, and Molecular Mechanisms of Heat Stress Tolerance in Plants. Int. J. Mol. Sci. 2013, 14, 9643-9684. [CrossRef]

4. Mathur, S.; Agrawal, D.; Jajoo, A. Photosynthesis: Response to high temperature stress. J. Photochem. Photobiol. B Biol. 2014, 137, 116-126. [CrossRef] [PubMed]

5. Sintayehu, D.W. Impact of climate change on biodiversity and associated key ecosystem services in Africa: A systematic review. Ecosyst. Health Sustain. 2018, 4, 225-239. [CrossRef]

6. Sorte, C.J.B.; Ibáñez, I.; Blumenthal, D.M.; Molinari, N.A.; Miller, L.P.; Grosholz, E.D.; Diez, J.M.; D’Antonio, C.M.; Olden, J.D.; Jones, S.J.; et al. Poised to prosper? A cross-system comparison of climate change effects on native and non-native species performance. Ecol. Lett. 2018, 16, 261-270. [CrossRef]

7. Zhang, Q.; Zhang, Y.; Peng, S.; Zobel, K. Climate Warming May Facilitate Invasion of the Exotic Shrub Lantana camara. PLoS ONE 2014, 9, e105500. [CrossRef]

8. IUCN. 100 of the World's Worst Invasive Alien Species; Invasive Species Specialist Group: Auckland, New Zealand, 2001.

9. Xie, Y.; Li, Z.; William, P.; Dianmo, L. Invasive species in China an overview. Biodivers. Conserv. 2001, 10, 1317-1341.

10. Song, L.; Chow, W.S.; Sun, L.; Li, C.; Peng, C. Acclimation of photosystem II to high temperature in two Wedelia species from different geographical origins: Implications for biological invasions upon global warming. J. Exp. Bot. 2010, 61, 4087-4096. [CrossRef]

11. Berry, J.; Bjorkman, O. Photosynthetic Response and Adaptation to Temperature in Higher Plants. Annu. Rev. Plant Physiol. 1980, 31, 491-543. [CrossRef]

12. Salvucci, M.; Crafts-Brandner, S. Relationship between the Heat Tolerance of Photosynthesis and the Thermal Stability of Rubisco Activase in Plants from Contrasting Thermal Environments. Plant Physiol. 2004, 134, 1460-1470. [CrossRef] [PubMed]

13. Mittler, R. Oxidative stress, antioxidants and stress tolerance. Trends Plant Sci. 2002, 7, 405-410. [CrossRef]

14. Djanaguiraman, M.; Boyle, D.L.; Welti, R.; Jagadish, S.V.K.; Prasad, P.V.V. Decreased photosynthetic rate under high temperature in wheat is due to lipid desaturation, oxidation, acylation, and damage of organelles. BMC Plant Biol. 2018, 18, 55. [CrossRef] [PubMed]

15. Bian, S.; Jiang, Y. Reactive oxygen species, antioxidant enzyme activities and gene expression patterns in leaves and roots of Kentucky bluegrass in response to drought stress and recovery. Sci. Hortic. 2009, 120, 264-270. [CrossRef] 
16. Zhao, X.; Huang, L.; Zhang, X.; Li, Z.; Peng, Y. Effects of Heat Acclimation on Photosynthesis, Antioxidant Enzyme Activities, and Gene Expression in Orchardgrass under Heat Stress. Molecules 2014, 19, 13564-13576. [CrossRef]

17. Song, L.; Sun, L.; Shu, Z.; Zeng, W.; Li, W.; Peng, C. Effects of drought stress and rehydration on chlorophyll fluorescence characteristics in leaves of invasive Wedelia trìlobata. Acta Ecol. Sin. 2009, 29, 3713-3721.

18. Cai, M.; Ding, W.; Zhai, J.; Zheng, X.; Yu, Z.; Zhang, Q.; Lin, X.; Chow, W.S.; Peng, C. Photosynthetic compensation of nonleaf organ stems of the invasive species Sphagneticola trilobata (L.) Pruski at low temperature. Photosynth. Res. 2020, 1-14. [CrossRef] [PubMed]

19. Wang, Z.B.; Li, G.F.; Sun, H.Q.; Ma, L.; Guo, Y.P.; Zhao, Z.Y.; Gao, H.; Mei, L.X. Effects of drought stress on photosynthesis and photosynthetic electron transport chain in young apple tree leaves. Biol. Open 2018, 7, bio035279. [CrossRef]

20. Huo, Y.J.; Wang, M.P.; Wei, Y.Y.; Xia, Z.L. Overexpression of the Maize psbA Gene Enhances Drought Tolerance Through Regulating Antioxidant System, Photosynthetic Capability, and Stress Defense Gene Expression in Tobacco. Front. Plant Sci. 2016, 6, 1223. [CrossRef]

21. Enami, I.; Kitamura, M.; Tomo, T.; Isokawa, Y.; Ohta, H.; Katoh, S. Is the primary cause of thermal inactivation of oxygen evolution in spinach PS II membranes release of the extrinsic $33 \mathrm{kDa}$ protein or of Mn? Biochim. Et Biophys. Acta (Bba) Bioenerg. 1994, 1186, 52-58. [CrossRef]

22. Li, H.; Ahammed, G.J.; Zhou, G.N.; Xia, X.J.; Zhou, J.; Shi, K.; Yu, J.Q.; Zhou, Y.H. Unraveling Main Limiting Sites of Photosynthesis under Below- and Above-Ground Heat Stress in Cucumber and the Alleviatory Role of Luffa Rootstock. Front. Plant Sci. 2016, 7, 746. [CrossRef] [PubMed]

23. Yin, Z.; Lu, J.; Gao, Z. Effects of Photosynthetic, PSII Electron Transport and Reactive Oxygen Species on Short-term High Temperature Stress in Tomato Seedlings. North. Hortic. 2019, 43, 1-11.

24. Crafts-Brandner, S.; Law, R. Effect of heat stress on the inhibition and recovery of the ribulose-1,5-bisphosphate carboxylase/oxygenase activation state. Planta 2000, 212, 67-174. [CrossRef] [PubMed]

25. Salvucci, M.; Crafts-Brandner, S. Inhibition of photosynthesis by heat stress: The activation state of Rubisco as a limiting factor in photosynthesis. Physiol. Plant. 2004, 120, 179-1186. [CrossRef]

26. Liu, M.; Gong, J.; Yang, B.; Ding, Y.; Zhang, Z.; Wang, B.; Zhu, C.; Hou, X. Differences in the photosynthetic and physiological responses of Leymus chinensis to different levels of grazing intensity. BMC Plant Biol. 2019, 19, 558. [CrossRef]

27. Tardy, F.; Creach, A.; Havaux, M. Photosynthetic pigment concentration, organization and interconversions in a pale green Syrian landrace of barley (Hordeum vulgare L., Tadmor) adapted to harsh climatic conditions. Plant Cell Environ. 1998, 21, 479-489. [CrossRef]

28. Song, Y.; Chen, Q.; Ci, D.; Shao, X.; Zhang, D. Effects of high temperature on photosynthesis and related gene expression in poplar. BMC Plant Biol. 2014, 14, 111. [CrossRef]

29. Liu, A.; Hu, Z.; Bi, A.; Fan, J.; Gitau, M.; Amombo, E.; Chen, L.; Fu, J. Photosynthesis, antioxidant system and gene expression of bermudagrass in response to low temperature and salt stress. Ecotoxicology 2016, 25, 1445-1457. [CrossRef]

30. Wahid, A.; Gelani, S.; Ashraf, M.; Foolad, M. Heat tolerance in plants: An overview. Environ. Exp. Bot. 2007, 61, 199-223. [CrossRef]

31. Zhang, J.; Li, Y. Degradation effects of active oxygen damage on garden plant seedling chlorophyll. J. Cent. South Univ. For. Technol. 2012, 32, 73-77. (In Chinese)

32. Takeuchi, Y.; Kubo, H.; Kasahara, H.; Sakaki, T. Adaptive Alterations in the Activities of Scavengers of Active Oxygen in Cucumber Cotyledons Irradiated with UV-B. J. Plant Physiol. 1996, 147, 589-592. [CrossRef]

33. Wang, W.B.; Kim, Y.H.; Lee, H.S. Analysis of antioxidant enzyme activity during germination of alfalfa under salt and drought stresses. Plant Physiol. Biochem. 2009, 47, 570-577. [CrossRef] [PubMed]

34. Du, H.; Zhou, P.; Huang, B. Antioxidant enzymatic activities and gene expression associated with heat tolerance in a cool-season perennial grass species. Environ. Exp. Bot. 2013, 87, 159-166. [CrossRef]

35. Tabart, J.; Kevers, C.; Evers, D.; Dommes, J. Ascorbic Acid, Phenolic Acid, Flavonoid, and Carotenoid Profiles of Selected Extracts from Ribes nigrum. J. Agric. Food Chem. 2011, 59, 4763-4770. [CrossRef] [PubMed]

36. Wellburn, A. The spectral determination of chlorophylls a and b, as well as total carotenoids, using various solvents with spectrophotometers of different resolution. J. Plant Physiol. 1994, 144, 307-313. [CrossRef]

37. Zheng, X.; Chen, Y.; Zhang, X.; Cai, M.; Yu, Z.; Peng, C. ANS-deficient Arabidopsis is sensitive to high light due to impaired anthocyanin photoprotection. Funct. Plant Biol. 2019, 46, 756-765. [CrossRef]

38. Wang, H.; Jin, J.Y. Photosynthetic rate, chlorophyll fluorescence parameters, and lipid peroxidation of maize leaves as affected by zinc deficiency. Photosynthetica 2005, 43, 591-596. [CrossRef]

39. Park, Y.; Jung, S.; Kang, S.; Kang, S.; Heo, B.; Arancibia-Avila, P.; Toledo, F.; Drzewiecki, J.; Namiesnik, J.; Gorinstein, S. Antioxidants and proteins in ethylene-treated kiwifruits. Food Chem. 2008, 107, 640-648. [CrossRef]

40. Cheung, L.M.; Cheung, P.C.K.; Ooi, V.E.C. Antioxidant activity and total phenolics of edible mushroom extracts. Food Chem. 2003, 81, 249-255. [CrossRef]

41. Zhu, H.; Zhang, T.; Zheng, J.; Huang, X.; Yu, Z.-C.; Peng, C.-L.; Chow, W.S. Anthocyanins function as a light attenuator to compensate for insufficient photoprotection mediated by nonphotochemical quenching in young leaves of Acmena acuminatissima in winter. Photosynthetica 2018, 56, 445-454. [CrossRef]

42. Tan, W.; Liu, J.; Dai, T.; Jing, Q.; Cao, W.; Jiang, D. Alterations in photosynthesis and antioxidant enzyme activity in winter wheat subjected to post-anthesis water-logging. Photosynthetica 2008, 46, 21-27. [CrossRef] 
43. Du, H.; Wang, Z.; Huang, B. Differential responses of warm-season and cool season turfgrass species to heat stress associated with antioxidant enzyme activity. J. Am. Soc. Hortic. Sci. 2009, 134, 417-422. [CrossRef]

44. Jiang, Y.; Huang, B. Drought and Heat Stress Injury to Two Cool-Season Turfgrasses in Relation to Antioxidant Metabolism and Lipid Peroxidation. Crop Sci. 2001, 41, 436. [CrossRef]

45. Nakano, Y.; Asada, K. Hydrogen peroxide is scavenged by ascorbate-specific peroxidase in spinach chloroplasts. Plant Cell Physiol. 1981, 22, 867-880.

46. Livak, K.; Schmittgen, T. Analysis of Relative Gene Expression Data Using Real-Time Quantitative PCR and the $2^{-\Delta \Delta C T}$ Method. Methods 2001, 25, 402-408. [CrossRef] [PubMed] 